\title{
Effect of carotenoid source and dietary lipid content on blood astaxanthin concentration in rainbow trout (Oncorhynchus mykiss)
}

\author{
M.J. Barbosa ${ }^{a}$, R. Morais ${ }^{\text {a }}$, G. Choubert ${ }^{\text {b,* }}$ \\ ${ }^{a}$ Laboratório de Biotecnologia Vegetal, Escola Superior de Biotecnologia-Universidade Católica \\ Portuguesa, R. Dr. Bernardino Almeida, 4200, Porto, Portugal \\ ${ }^{\mathrm{b}}$ Laboratoire de Nutrition des Poissons, Unité mixte INRA-INFREMER, Station d'Hydrobiologie, 64310 \\ Saint-Pée-sur-Nivelle, France
}

\begin{abstract}
Astaxanthin concentration in the blood of rainbow trout was studied in a feeding trial with two different astaxanthin sources: green algae Haematococcus pluvialis and commercial beadlets of $8 \%$ astaxanthin content (CAROPHYLL ${ }^{\circledR}$ Pink), and two different dietary lipid levels. The green algae contained $1.4 \%$ of carotenoids on a dry matter basis: free astaxanthin $(<1 \%)$, astaxanthin monoester $(24.3 \%)$; astaxanthin diester $(70.2 \%)$ and lutein $(4.8 \%)$. Algal biomass was mechanically ground to disrupt the cell wall before incorporation in the feed. Hydrolysis of astaxanthin esters from algae occurred during the pelletization even at a low process temperature $\left(43^{\circ} \mathrm{C}\right)$. Rainbow trout with an initial mean body weight of $150 \mathrm{~g}$ were fed experimental diets supplemented at a rate of $100 \mathrm{mg}$ pigment $/ \mathrm{kg}$ diet combined with two different lipid levels (9 and 24\%) during 5 days. Astaxanthin concentration in the serum ranged from $5.3 \mu \mathrm{g} / \mathrm{ml}(8.9 \mathrm{nmol} / \mathrm{ml})$ to $9.0 \mu \mathrm{g} / \mathrm{ml}(15.1 \mathrm{nmol} / \mathrm{ml})$. Astaxanthin concentration in the serum was higher for fish fed high lipid level diets, independently of the astaxanthin source. No differences in the astaxanthin serum concentration were found for fish fed diets supplemented with either natural or synthetic astaxanthin, respectively $9.0 \pm 1.9$ and $8.4 \pm 2.4 \mu \mathrm{g}$ astaxanthin $/ \mathrm{ml}$ serum, when dietary lipid level was high (24\%). On the other hand, there was a higher blood astaxanthin concentration in fish fed diets supplemented with algal biomass $(7.0 \pm 2.4 \mu \mathrm{g}$ astaxanthin/ml serum) compared to
\end{abstract}

Keywords: Haematococcus; Carotenoid; Astaxanthin; Dietary lipid level; Serum; Rainbow trout

\footnotetext{
* Corresponding author. Tel.: +33-05-59-51-59-51; Fax: +33-05-59-54-51-52; E-mail: choubert@st-pee.inra.fr
} 
synthetic astaxanthin $(5.3 \pm 2.0 \mu \mathrm{g}$ astaxanthin $/ \mathrm{ml}$ serum $)$ when dietary lipid level was low (9\%).

\section{Introduction}

Carotenoids are the main pigments of many aquatic animals. In salmonids, astaxanthin is responsible for the typical red colour of the flesh. Salmonids cannot synthetise carotenoids de novo and therefore depend entirely on dietary supplements to achieve their natural pigmentation. Astaxanthin and canthaxanthin are commonly used in the diets of farmed salmonids to produce coloration similar to wild fish. Astaxanthin is preferable to canthaxanthin because it produces nature-identical pigmentation and is more efficiently deposited (Foss et al., 1984; Torrissen, 1986; Storebakken et al., 1987).

The freshwater, unicellular green alga Haematococcus pluvialis has been recognised for many years as an accumulator of the carotenoid astaxanthin (Goodwin and Jamirkon, 1954; Czygan, 1968; Kobayashi et al., 1991). Under certain stress conditions, such as high irradiance and nitrogen limitation, cells of this alga form cysts and accumulate massive amounts of astaxanthin in their cytoplasm to the extent that their colour changes from green to red (Goodwin and Jamirkon, 1954; Borowitzka et al., 1991; Yong and Lee, 1991; Boussiba et al., 1992; Fan et al., 1994). This alga has recently received much attention due to its capability to synthetise and accumulate large amounts of astaxanthin during and at the end of the growth phase ( $>1 \%$ of dry weight) (Czygan, 1968; Johnson and An, 1991; Sommer et al., 1991, 1992; Choubert and Heinrich, 1993; Cordero et al., 1996).

Trout flesh pigmentation depends not only on the occurrence of carotenoids in the feed, but also on other factors such as absorption and transport in the blood that limit as well the amount of astaxanthin retained in the muscle. The muscle retention of astaxanthin represents only 3-18\% of the ingested pigment (Storebakken and Choubert, 1991; Choubert et al., 1995; Nickell and Bromage, 1998) which may be explained in part by the low digestibility of astaxanthin (Foss et al., 1987). A better understanding of astaxanthin absorption may allow for a better utilisation of this compound by fish and lead to a reduction of production costs as pigment supplementation represents as much as $10-15 \%$ of the total feed costs (Torrissen et al., 1990).

As carotenoids are fat soluble compounds, the effect of dietary lipid level on astaxanthin absorption is of interest as it might increase the absorption. In humans it is known that the absence of dietary fat or very low levels of fat in the diets, substantially reduces human carotenoid absorption (Erdman, 1988; Erdman et al., 1993; Prince and Frisoli, 1993). Dietary lipid effect on muscle retention has been investigated in fish and contradictory results have been reported (Abdul-Malak, 1975; Seurman et al., 1979; Choubert and Luquet, 1983; Torrissen, 1985; Nickell and Bromage, 1998). However, serum astaxanthin concentration in fish, in response to different dietary lipid levels, has not yet been studied and it could help to clarify the effects of lipid on astaxanthin utilisation by rainbow trout. 
The current experiment was designed to study astaxanthin concentration in the blood of rainbow trout fed diets supplemented with different sources of astaxanthin: green algae $H$. pluvialis and synthetic astaxanthin (CAROPHYLL ${ }^{\circledR}$ Pink), at two different dietary lipid levels (9 and 24\%). Relative serum concentrations of astaxanthin were taken as an indication of differences in pigment absorption (March and MacMillan, 1996).

\section{Materials and methods}

\subsection{Carotenoid sources}

The microalga $H$. pluvialis strain CCAP H35 was cultivated in Bold basal medium (Nichols and Bold, 1964). The culture grew in a 101 plexyglass cylinder into which air was bubbled agitating the culture for 2 weeks. Temperature was maintained at $21 \pm 1^{\circ} \mathrm{C}$ with a $12 \mathrm{~h}$ dark: $12 \mathrm{~h}$ light cycle. Illumination was provided by cool white fluorescent lamps (L36 W/21 Hellweiss Luminux Coolwhite, Osram, Lisbon, Portugal) at an irradiance of $46 \mu \mathrm{mol}$ photons $/ \mathrm{m}^{2}$ per s. In order to stimulate astaxanthin production, the cultivated algae were moved to another temperature controlled chamber for 3 days where the temperature was $30 \pm 1{ }^{\circ} \mathrm{C}$ and light intensity to $80 \mu \mathrm{mol}$ photons $/ \mathrm{m}^{2}$ per s. The $12 \mathrm{~h}$ dark: $12 \mathrm{~h}$ light cycle was maintained. Algae were harvested by centrifugation (XL-80 ultracentrifuge, Beckman Instruments, Fullerton, USA) at $1000 \times g$ for 5 min, washed with distilled water and centrifuged for another $5 \mathrm{~min}$. The biomass was then recovered and put in a biofreezer (Model 8417 S/N 85162-2127, Forma Scientific, Marietta, USA) at $-80^{\circ} \mathrm{C}$ for $24 \mathrm{~h}$ after which it was lyophilised for 3 days (CHRIST ALPHA 1-4, Biotech, Osterode, Germany) and finally stored under nitrogen at $-18^{\circ} \mathrm{C}$. Before incorporation into experimental diets, the algal biomass was mechanically ground in a ball grinder (grinder Dangoumeau, Prolabo, Paris, France) for 5 min to disrupt the cell walls. Grinding efficiency was assessed by microscope observation.

Astaxanthin was added to the feed as water dispersable beadlets (CAROPHYLL ${ }^{\circledR}$ Pink, F. Hoffmann-La Roche, Basel, Switzerland) of $8 \%(\mathrm{w} / \mathrm{w})$ astaxanthin content. The beadlet formulation consisted of emulsified droplets of astaxanthin in peanut oil encased in a matrix of gelatin, sucrose and food starch, and stabilised by addition of ascorbyl palmitate and all-rac- $\alpha$-tocopherol as antioxidants (Klãui and Bauernfeind, 1981).

Four diets were prepared using the two astaxanthin sources and two different lipid levels (9 and 24\%). The basal composition of each diet was that of Boujard and Médale (1994). Astaxanthin supplements were thoroughly mixed with the feed at a rate of 100 $\mathrm{mg}$ carotenoid $/ \mathrm{kg}$ of feed before pelletization. Diets were pelleted using a dry, steamless pelleting machine (Regina Supernova, Italy) through a $4.5 \mathrm{~mm}$ dye. The pelleted diets thus obtained were allowed to dry at $38^{\circ} \mathrm{C}$ for $22 \mathrm{~h}$ and were stored at $+4^{\circ} \mathrm{C}$ prior to use in the week after. The proximate composition of the experimental diets is given in Table 1 . 
Table 1

Proximate composition of the experimental diets (mean of two determinations)

\begin{tabular}{lcrrr}
\hline & \multicolumn{2}{c}{ Diets $^{\mathrm{a}}$} & \multicolumn{2}{c}{ ALLE } \\
\cline { 2 - 5 } & AXHE & ALHE & AXL & ALLE \\
\hline Dry matter (DM) (\%) & 95.3 & 95.6 & 94.3 & 37.8 \\
Protein (\% DM) & 39.3 & 38.5 & 38.3 & 9.3 \\
Lipid (\% DM) & 24.4 & 25.1 & 9.6 & 9.9 \\
Ash (\% DM) & 10.7 & 10.3 & 119.7 & 142.0 \\
Astaxanthin (mg/kg of feed DM) & 110.1 & 129.8 & 9.9 & \\
\hline
\end{tabular}

${ }^{a}$ Diets were designed by their carotenoid source (two first letters) and lipid level (two last letters): $\mathrm{AX}=$ synthetic astaxanthin, $\mathrm{AL}=$ microalgal astaxanthin; $\mathrm{HE}=$ high lipid content; $\mathrm{LE}=$ low lipid content.

\subsection{Fish and experimental conditions}

The experiment took place at the INRA experimental fish farm of Donzacq (Landes department, France). Rainbow trout (Oncorhynchus mykiss) 16 months old and from the same parental stock were provided by the INRA hatchery of Lees-Athas (Pyrénées Atlantiques department, France). Eighty fish with a mean weight of $150 \mathrm{~g}$ were divided among eight different groups and held in a $0.5 \mathrm{~m}^{3}$ fiber glass tank supplied by spring water (pH: $\left.7.4, \mathrm{Cl}^{-}: 22.5 \mathrm{mg} / 1, \mathrm{Ca}^{2+}: 75 \mathrm{mg} / \mathrm{l}\right)$ at a constant temperature $\left(17 \pm 1^{\circ} \mathrm{C}\right)$ and a rate of 5 volume changes per hour. Fish were maintained on a commercial non-pigmented trout feed (Trouw France, Fontaine-les-Vervins, France) for 11 days prior to feeding the four experimental diets, tested in duplicate. Fish were hand-fed twice a day a weighed quantity of feed during 5 days and complete feed ingestion was assessed visually. Astaxanthin intake per experimental diet is reported in Fig. 2.

\subsection{Sampling and analytical methods}

Blood sampling was carried out at the end of the experiment. The time elapsed between the last meal and blood sampling was within $2 \mathrm{~h}$. Blood was collected from the 80 fish from the caudal artery with $2 \mathrm{ml}$ non-heparinized disposable syringes fitted with $0.6 \times 25 \mathrm{~mm}$ disposable needles (Becton Dickinson France, Le Pont de Claix, France). Blood samples (approx. $2 \mathrm{ml} /$ fish) were held overnight at $+4^{\circ} \mathrm{C}$ to clot. Samples were centrifuged at $1000 \times g$ (Model T52.1, MLW, Engelsdorf, Germany) for 5 min. The serum was then removed with a Pasteur pipette.

Carotenoid analyses were carried out in duplicate, and the general precautions recommended for isolation and handling of carotenoids (Fiasson et al., 1969) were followed.

For astaxanthin analyses, serum $(0.2 \mathrm{ml})$ was vortexed with $0.4 \mathrm{ml}$ of ethanol $\left(95^{\circ}\right)$ for $30 \mathrm{~s}$, then $1 \mathrm{ml}$ of hexane was added, and the mixture was vortexed for $1 \mathrm{~min}$. The hexane was separated by centrifuging at $1000 \times g$ for $5 \mathrm{~min}$. Absorbance was measured at $480 \mathrm{~nm}$ in $n$-hexane by UV-visible spectrophotometry (UV-160A, Shimadzu, Tokyo, Japan). Astaxanthin concentration was calculated using a specific extinction coefficient $E_{1 \mathrm{~cm}}^{1 \%}=2100$ in $n$-hexane (Weber, 1988). 
Table 2

Carotenoid pigments in the alga $H$. pluvialis (mean of two determinations)

\begin{tabular}{lc}
\hline Carotenoid & Percent of total carotenoids $(\mathrm{DM})^{\mathrm{a}}$ \\
\hline Astaxanthin diester & 70.2 \\
Astaxanthin monoester & 24.3 \\
Free astaxanthin & $<1$ \\
Lutein & 4.8 \\
\hline
\end{tabular}

${ }^{\mathrm{a}}$ Dry matter basis.

For carotenoid extraction from the microalgal biomass, a sample of algal powder was weighted into a glass flask (Virtis, New York, USA) and $45 \mathrm{ml}$ of acetone were added. The mixture was homogenized with a homogenizer (Virtis '45' Homogenizer, Virtis) for $2 \mathrm{~min}$ at $20000 \mathrm{rpm}$ and the homogenate was vacuum-filtered through glass microfibre filters (GF/A, Whatman International, Maidstone, England). Silica was added to the filter to avoid fouling. The procedure was repeated three times until the filtrate was colourless. The extract was pooled and mixed with $50 \mathrm{ml}$ of petroleum ether (b.p. $40-60^{\circ} \mathrm{C}$ ) and $37.5 \mathrm{ml}$ of sodium chloride solution $0.73 \%$ in a $250 \mathrm{ml}$ separatory funnel. Phase separation was allowed, epiphase was recovered into a round flask and an equal volume of water was added to the remaining solution. After mixing and phase separation, the epiphase was again recovered into the same balloon and dried under vacuum in a rotary evaporator (Büchi rotavapor, Büchi Laboratoriums-Technik, Flawil, Switzerland) at $40^{\circ} \mathrm{C}$. The extracts were then redissolved in acetone. Total carotenoid concentration was calculated from the peak absorbances using a specific extinction

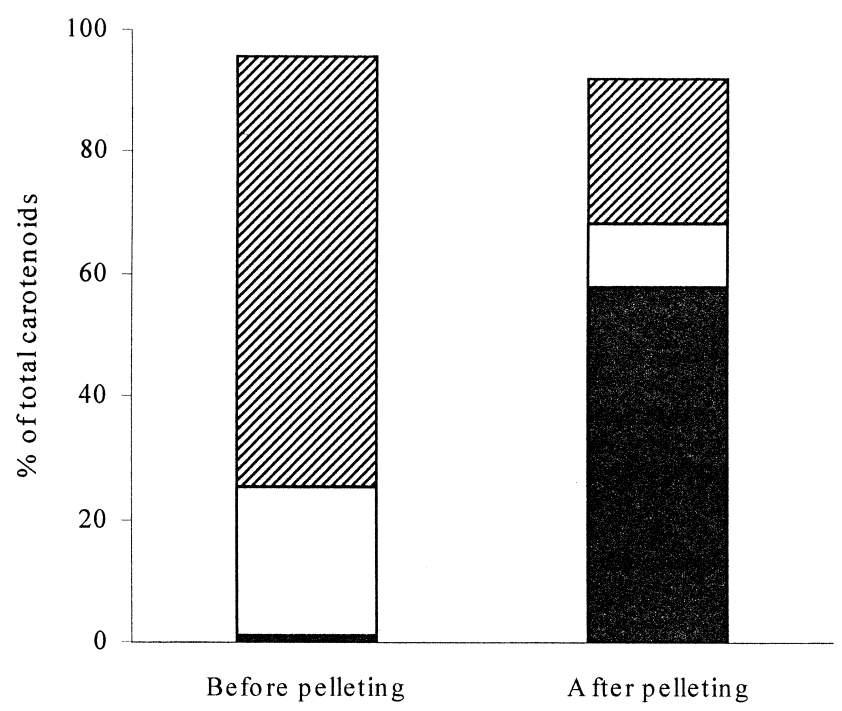

Fig. 1. Changes in astaxanthin forms during pelleting process. Astaxanthin diester $\square 7$, astaxanthin monoester $\square$ and free astaxanthin 
coefficient $E_{1 \mathrm{~cm}}^{1 \%}=2100$ in $n$-hexane (Weber, 1988), after scanning the algal extracts between $380-600 \mathrm{~nm}$ by UV-visible spectrophotometry (UV-160A, Shimadzu).

The major carotenoids in the algal powder were identified and quantified by thin-layer chromatography (Goodwin, 1955) on TLC plated silica gel, $20 \times 20 \mathrm{~cm}$ layer, thickness $0.25 \mathrm{~mm}$ (TLC plated silica gel 60, Merck, Darmstadt, Germany) with authentic standards for canthaxanthin and astaxanthin (F. Hoffmann-La Roche). The developing mixture was petroleum ether (b.p. $\left.40-60^{\circ} \mathrm{C}\right) /$ acetone $(3: 1, v / v)$ (Fiasson et al., 1969). In a diffused light, the different TLC bands were scrapped off, eluted with acetone and vacuum filtered. Each filtrate was dried under vacuum in a rotary evaporator (Büchi rotavapor, Büchi Laboratoriums-Technik) and redissolved in $n$-hexane prior to quantification in a spectrophotometer (UV-160A, Shimadzu). Each carotenoid concentration was calculated from the peak absorbances using the extinction coefficient $E_{1 \mathrm{~cm}}^{1 \%}=2100$ for free, monoester and diester astaxanthin in $n$-hexane and $E_{1 \mathrm{~cm}}^{1 \%}=2500$ for lutein in ethanol (Weber, 1988).

Synthetic astaxanthin in the diets was analysed according to Osadca et al. (1972). Microalgal astaxanthin in the diets was extracted with the lipids following the method of Folch et al. (1957) and quantified by spectrophotometry.

Group comparisons between the different diets were made for carotenoid absorption by Student's $t$-test (Zar, 1984). A significance level of $P<0.05$ was used to determine statistically significant differences between means.

\section{Results}

The total amount of carotenoid pigments in the algal biomass was $1.4 \%$ on a dry weight basis. The major pigments of the algae are reported in Table 2. Ketocarotenoids comprised $95.5 \%$. Diets containing microalgal astaxanthin were formulated taking into

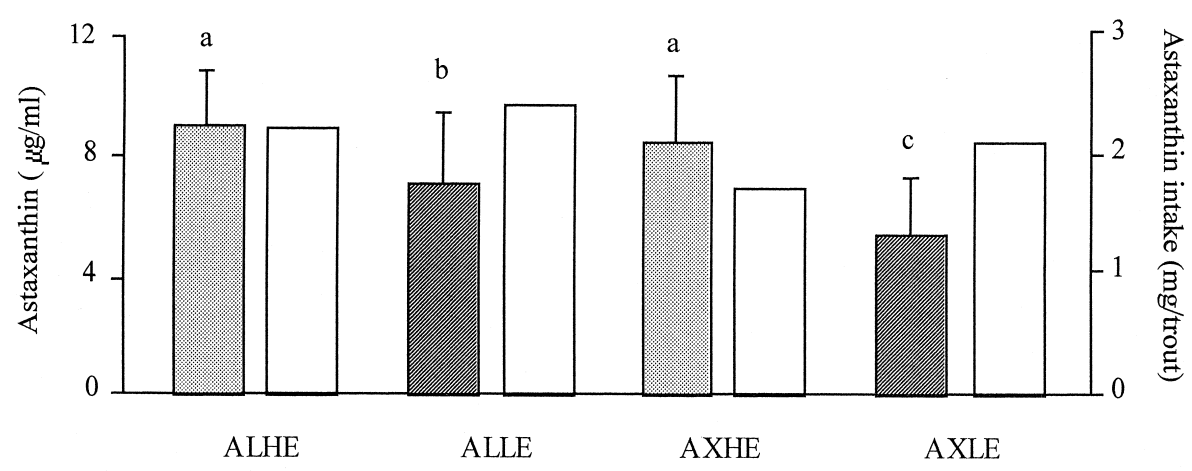

Experimental diets

Fig. 2. Serum astaxanthin concentration of rainbow trout fed either microalgal astaxanthin (AL) or synthetic

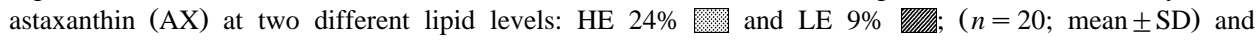
astaxanthin intake (mg/trout) $\square$. Means with no common letters differ significantly $(P<0.05)$. 
account the astaxanthin profile of the algae. Analyses of extracts from the diets supplemented with algal biomass gave the following composition: free astaxanthin $58.0 \%$, astaxanthin monoester $10.3 \%$, astaxanthin diester $23.8 \%$, and lutein $7.8 \%$ (Fig. 1).

Results for serum astaxanthin concentration and carotenoid intake are given in Fig. 2. Levels of serum astaxanthin concentration ranged from $5.3 \pm 2.0 \mu \mathrm{g} / \mathrm{ml}$ to $9.0 \pm 1.9$ $\mu \mathrm{g} / \mathrm{ml}$.

Astaxanthin concentration in the serum was higher $(P<0.05)$ for fish fed high lipid level diets, independent of the astaxanthin source. The concentration of astaxanthin in the serum was higher $(P<0.05)$ in fish fed diets supplemented with microalgal astaxanthin $(7.0 \pm 2.5 \mu \mathrm{g}$ astaxanthin $/ \mathrm{ml})$ compared to synthetic astaxanthin $(5.3 \pm 2.0$ $\mu \mathrm{g}$ astaxanthin/ml) when dietary lipid level was low (9\%). However, there were no significant differences between astaxanthin concentration in the serum in fish fed either synthetic or microalgal supplemented diets, respectively $8.4 \pm 2.4$ and $9.0 \pm 1.9 \mu \mathrm{g}$ astaxanthin /ml serum when dietary lipid level was high (24\%).

\section{Discussion}

The major pigments found in $H$. pluvialis are generally $\beta$-carotene and its keto-derivatives echinenone, canthaxanthin and astaxanthin. These additional pigments are found outside the chloroplast, in the aplanospores (Czygan and Kessler, 1967). This can explain some of the discrepancies observed in the carotenoid composition between algae used in this study and previous results reported for algae of different strains and cultivated under different conditions (Kuhn et al., 1939; Czygan, 1968, 1970; Renstrøm et al., 1981). Nevertheless, analyses of the algae used in this study confirmed the presence of astaxanthin as the major red carotenoid pigment in an amount as high as $95.5 \%$ of total carotenoids.

Highly pigmented cells of the microalga occur in an encysted form surrounded by a thick cell wall and this barrier may impede the absorption of pigments by fish (Johnson and An, 1991; Choubert and Heinrich, 1993). Therefore, carotenoids are available to fish only if the algal cell is broken mechanically or chemically, since fish do not possess enzymes capable of breaking the alga cell wall. The non or incomplete breakage of the cell wall may explain the low levels obtained for microalgal astaxanthin deposition in the fish flesh compared to synthetic astaxanthin (Sommer et al., 1991, 1992; Choubert and Heinrich, 1993). Therefore, the algal biomass used in this experiment was mechanically ground before incorporation in the feed.

Degradation of algal carotenoids occurred during the pelleting process $(3.4 \%$ of total astaxanthin as a percentage of total carotenoids) which may be due to an increase in temperature and pressure in the pelleting machine even at a low temperature $\left(43^{\circ} \mathrm{C}\right)$ (Wornick, 1960). This finding is in agreement with Choubert and Heinrich (1993). However, the increase of free astaxanthin in the feed after pelletization may be due to hydrolysis of astaxanthin esters during the process.

Astaxanthin concentration was measured in the serum since it has been reported that plasma extract showed up to $10 \%$ lower carotenoid concentrations as compared with the 
serum extract (Nierenberg, 1984; Stacwicz-Sapuntzakis et al., 1987). Fish were fed over 5 days to assure that astaxanthin serum concentration was maximum, since a plateau of concentration is reached after 1 day of astaxanthin intake (Choubert et al., 1994).

The time elapsed between the meal and blood sampling was $2 \mathrm{~h}$ since it has been reported that the decrease of astaxanthin in the serum is a fast phenomenon (Choubert et al., 1994).

Astaxanthin concentrations in the serum at the end of experiment in all the fish fed the four experimental diets were in the range of serum/plasma carotenoid values reported in the literature for immature rainbow trout (Choubert et al., 1987, 1992) and higher than that obtained by March et al. (1990). However, reported values refer to synthetic astaxanthin. No work has been conducted on algal astaxanthin. Considerable interindividual variations in the amount of astaxanthin in the serum appeared. This variability has been reported in other fish carotenoid studies (Choubert et al., 1987; March et al., 1990; Guillou et al., 1992; Gobantes et al., 1997).

Results obtained in this experiment, concerning the effect of dietary lipid level on astaxanthin serum concentration, showed that astaxanthin concentration was higher for fish fed high dietary lipid level, independent of the astaxanthin source. These results were expected since carotenoids are fat soluble compounds. The results are in agreement with those of Erdman (1988) and Prince and Frisoli (1993), who reported that the absence or very low levels of fat in diets substantially reduced human carotenoid absorption. In humans, dietary fat stimulates bile flow from the gall bladder, which facilitates the emulsification of fat and fat-soluble compounds into lipid micelles within the small intestine. Without micelle formation, carotenoids are poorly absorbed (Erdman, 1988).

Regarding the two astaxanthin sources, no difference in astaxanthin serum concentration was found in fish fed diets supplemented with either natural or synthetic astaxanthin when dietary lipid level was high.

A higher astaxanthin serum concentration was found in fish fed diets supplemented with algal biomass when dietary lipid level was low. The reason why algal astaxanthin concentration in the serum is higher than that of synthetic astaxanthin only in fish fed low lipid levels is not known and remains hypothetical. The esterified forms of astaxanthin present in algal biomass, even though at lower quantities after pelleting, were better absorbed than the synthetic astaxanthin (free form). This finding supports the idea that the cleavage of the astaxanthin esters is not a limiting step for microalgal astaxanthin absorption since only free astaxanthin is found in the serum, this indicated that astaxanthin esters are hydrolysed in the digestive tract and that astaxanthin is absorbed in the free state (Khare et al., 1973; Hata and Hata, 1975; Schiedt et al., 1986). However, the free form of astaxanthin was reported to be more efficiently utilized than the dipalmitate ester (Storebakken et al., 1987). The presence of phospholipids in the alga may increase the absorption of carotenoids since dietary phospholipids stimulated the absorption of dietary fatty acids in post-larval turbot (Geurden et al., 1998). Moreover, a specific enhancement of the secretion of intestinal lipoproteins by phosphatidylcholine was reported in rat cell lines by Field and Mathur (1995).

In conclusion, whatever the astaxanthin source, the high dietary lipid level increased serum astaxanthin concentration in fish. 
Results concerning pigment effect on serum astaxanthin concentrations showed that microalgal and synthetic astaxanthin were used by fish at the same extend when lipid level in the diet was high. Nevertheless, microalgal astaxanthin was better used than synthetic astaxanthin when dietary lipid level was low.

\section{Acknowledgements}

The authors thank Laurence Larroquet for her technical support, and the staff at the INRA Experimental Fish Farm at Donzacq (Yves Hontang, Frédéric Terrier and Franck Sandres) for the care and feeding of the fish. We also thank the PRAXIS XXI through the project PRAXIS XXI/2/2.1/BIO/1065/95 for financial support, F. Hoffman-La Roche (Basel, Switzerland) for providing carotenoids standards and Produits Roche France (Neuilly-sur-Seine, France) for providing CAROPHYLL ${ }^{\circledR}$ Pink. M.J. Barbosa's stay in France was made possible through the Portugal-France Scientific and Technical Cooperation Exchange Programme (JNICT-French Embassy at Lisbon, Portugal, project 1997/030-P8).

\section{References}

Abdul-Malak, N., 1975. Influence de certains facteurs nutritionnels et écologiques sur le métabolisme d'un pigment caroténoide: la canthaxanthine chez la truite (Salmo gairdneri R.). Thèse Doctorat 3ème cycle, Lyon, 106 pp.

Borowitzka, G.A., Huisman, J.M., Osborn, A., 1991. Culture of the astaxanthin-producing green alga Haematococcus pluvialis: I. Effects of nutrients on growth and cell type. J. Appl. Phycol. 3, $295-304$.

Boujard, T., Médale, F., 1994. Regulation of voluntary feed intake in juvenile rainbow trout fed by hand or by self-feeders with diets containing two different protein/energy ratios. Aquat. Living Resour. 7, 211-215.

Boussiba, S., Fan, L., Vonshak, A., 1992. Enhancement and determination of astaxanthin accumulation in green alga Haematococcus pluvialis. Methods Enzymol. 213, 386-391.

Choubert, G., Heinrich, O., 1993. Carotenoid pigments of the green alga Haematococcus pluvialis: assay on rainbow trout, Oncorhynchus mykiss, pigmentation in comparison with synthetic astaxanthin and canthaxanthin. Aquaculture 112, 217-226.

Choubert, G., Luquet, P., 1983. Utilization of shrimp meal for rainbow trout (Salmo gairdneri Rich.) pigmentation. Influence of fat content in the diet. Aquaculture 32, 19-26.

Choubert, G., Guillou, A., Fauconneau, B., 1987. Absorption and fate of labelled canthaxanthin $15,15^{\prime}-{ }^{3} \mathrm{H}_{2}$ in rainbow trout (Salmo gairdneri Rich.). Comp. Biochem. Physiol. 87 A, 717-720.

Choubert, G., Milicua, J., Gómez, R., Sancé, S., Petit, H., Négres-Sadargues, G., Castillo, R., Trilles, J.P., 1992. Distribution of canthaxanthin in immature rainbow trout Oncorhynchus mykiss serum. Comp. Biochem. Physiol. 103 A, 403-405.

Choubert, G., Gómez, R., Milicua, J.C.G., 1994. Response of serum carotenoid levels to dietary astaxanthin and canthaxanthin in immature rainbow trout Oncorhynchus mykiss. Comp. Biochem. Physiol. 109 A, 1001-1006.

Choubert, G., Milicua, G., Gómez, R., Sancé, S., Petit, H., Négres-Sadargues, G., Castillo, R., Trilles, J.P., 1995. Utilization of carotenoids from various sources by rainbow trout: muscle colour, carotenoid digestibility and retention. Aquacult. Int. 3, 1-12.

Cordero, B., Otero, A., Patiño, M., Arredondo, B.O., Fabregas, J., 1996. Astaxanthin production from the green alga Haematococcus pluvialis with different stress conditions. Biotechnol. Lett. 18, 213-218.

Czygan, F.-C., 1968. Secondary carotenoids in green algae: II. Studies on biogenesis. Arch. Mikrobiol. 62, $201-236$. 
Czygan, F.-C., 1970. Blutregen and Blutschnee: Stickstoffmangel-Zellen von Haematococcus pluvialis und Chlamydomonas nivalis. Arch. Mikrobiol. 74, 69-76.

Czygan, F.-C., Kessler, E., 1967. Nachweis von 3-Oxi-4,4'-dioxo- $\beta$-carotin in den Grünalgen Chlorococcum wimmeri und Haematococcus spec. Z. Naturforsch. 22b, 1085-1086.

Erdman, J.W. Jr., 1988. The physiologic chemistry of carotenes in man. Clin. Nutr. 7, 101-106.

Erdman, J.W. Jr., Bierer, T.L., Gugger, E.T., 1993. Absorption and transport of carotenoids. Ann. N.Y. Acad. Sci. 691, 76-85.

Fan, L., Vonshak, A., Boussiba, S., 1994. Effect of temperature and irradiance on growth of Haematococcus pluvialis (Chlorophyceae). J. Phycol. 30, 829-833.

Fiasson, J.-L., Arpin, N., Lebreton, P., 1969. Sur l'analyse qualitative et quantitative des caroténoïdes naturels. Chim. Anal. 51, 227-236.

Field, F.G., Mathur, S.N., 1995. Intestinal lipoprotein synthesis and secretion. Prog. Lipid Res. 34, 185-198.

Folch, J., Lees, M., Sloane Stanley, G.H., 1957. A simple method for the isolation and purification of total lipids from animal tissues. J. Biol. Chem. 226, 497-509.

Foss, P., Storebakken, T., Schiedt, K., Liaaen-Jensen, S., Austreng, E., Streiff, K., 1984. Carotenoids diets for salmonids: I. Pigmentation of rainbow trout with individual optical isomers of astaxanthin in comparison with canthaxanthin. Aquaculture 4, 213-226.

Foss, P., Storebakken, T., Austreng, E., Liaaen-Jensen, S., 1987. Carotenoids in diets for salmonids: V. Pigmentation of rainbow trout and sea trout with astaxanthin and astaxanthin dipalmitate in comparison with canthaxanthin. Aquaculture 65, 293-305.

Geurden, I., Bergot, P., Schwarz, L., Sorgeloos, P., 1998. Relationship between dietary phospholipid classes and neutral lipid absorption in newly-weaned turbot, Scophthalmus maximus. Fish Physiol. Biochem. 19, $217-228$.

Gobantes, I., Choubert, G., Laurentie, M., Milicua, J.-C.G., Gomez, R., 1997. Astaxanthin and canthaxanthin kinetics after ingestion of individual doses by immature rainbow trout, Oncorhynchus mykiss. J. Agric. Food. Chem. 45, 454-458.

Goodwin, T.W., 1955. Carotenoids. In Paech, K., Tracey, M.V. (Eds.), Modern Methods of Plant Analysis, Vol. III. Springer-Verlag, Berlin, Germany, pp. 272-311.

Goodwin, T.W., Jamirkon, M., 1954. Studies in carotenogenesis: II. Carotenoid synthesis in the alga Haematococcus pluvialis. Biochem. J. 57, 376-381.

Guillou, A., Choubert, G., de la Noüe, J., 1992. Absorption and blood clearance of labelled carotenoids $\left({ }^{14} \mathrm{C}\right.$-astaxanthin, ${ }^{3} \mathrm{H}$-cantaxanthin and ${ }^{3} \mathrm{H}$-zeaxanthin) in mature female rainbow trout, Oncorhynchus mykiss. Comp. Biochem. Physiol. 103A, 301-306.

Hata, M., Hata, M., 1975. Carotenoid pigments in rainbow trout Salmo gairdneri irideus. Tohoku J. Agric. Res. 26, 35-40.

Johnson, E.A., An, G.-H., 1991. Astaxanthin from microbial sources. Crit. Rev. Biotechnol. 11, 297-326.

Khare, A., Moss, G.P., Weedon, C.B.L., Matthews, A.D., 1973. Identification of astaxanthin in Scottish salmon. Comp. Biochem. Physiol. 45B, 971-974.

Klãui, H., Bauernfeind, J.C., 1981. Carotenoid analytical methods. In: Bauernfeind, J.C. (Ed.), Carotenoids as Colorants and Vitamin A Precursors. Academic Press, New York, pp. 47-317.

Kobayashi, M., Kakizono, T., Nagai, S., 1991. Astaxanthin production by a green alga Haematococcus pluvialis accompanied with morphological changes in acetate media. J. Ferment. Bioeng. 71, 335-339.

Kuhn, R., Stene, J., Sörensen, N.A., 1939. Uber die Verbreitung des Astaxanthins im Tierund Pflanzenreich. Ber. Chem. Ges. 72, 1688-1701.

March, B.E., Hajen, W.E., Deacon, G., MacMillan, C., Walsh, M.G., 1990. Intestinal absorption of astaxanthin, plasma astaxanthin concentration, body weight, and metabolic rate as determinants factors of flesh pigmentation in salmonid fish. Aquaculture 90, 313-322.

March, B.E., MacMillan, C., 1996. Muscle pigmentation and plasma concentrations of astaxanthin in rainbow trout, chinook salmon, and atlantic salmon in response to different dietary levels of astaxanthin. Prog. Fish-Cult. 58, 178-186.

Nichols, H.W., Bold, H.C., 1964. Trichsarcina polymorpha gen. et sp. nov. J. Phycol. 1, 34-38.

Nickell, D.C., Bromage, N.R., 1998. The effect of lipid level on variation of flesh pigmentation in rainbow trout (Oncorhynchus mykiss). Aquaculture 161, 237-251. 
Nierenberg, D.W., 1984. Determinations of serum and plasma concentrations of retinol using high performance liquid chromatography. J. Chromatogr. 311, 239-248.

Osadca, M., Araujo, M., De Ritter, E., 1972. Determination of partition coefficients in concentrates and feeds. J. Assoc. Off. Anal. Chem. 55, 110-113.

Prince, M.R., Frisoli, J.K., 1993. Beta-carotene accumulation in serum and skin. Am. J. Clin. Nutr. 57, $175-181$.

Renstrøm, B., Borch, G., Skulberg, O.M., Liaaen-Jensen, S., 1981. Optical purity of (3S,3'S)-astaxanthin from Haematococcus pluvialis. Phytochemistry 20, 2561-2564.

Seurman, L., Martinsen, C., Little, A., 1979. The effect of dietary lipid and pigment concentration in the feed of Salmo gairdneri on sensory characteristics and objective measurements of the fish muscle tissue. In: Halver, J.E., Tiews K., (Eds.), Finfish Nutrition and Fishfeed Technology, Vol. 2. Heinemann, Berlin, pp. 402-413.

Schiedt, K., Vecchi, M., Glinz, E., 1986. Astaxanthin and its metabolites in wild rainbow trout (Salmo gairdneri R.). Comp. Biochem. Physiol. 83B, 9-12.

Sommer, T.R., Potts, W.T., Morrissy, N.M., 1991. Utilization of microalgal astaxanthin by rainbow trout. Aquaculture 94, 79-88.

Sommer, T.R., Da Souza, F.M.L., Morrisy, N.M., 1992. Pigmentation of adult rainbow trout, Oncorhynchus mykiss, using the green alga Haematococcus pluvialis. Aquaculture 106, 63-74.

Stacwicz-Sapuntzakis, M., Bowen, P.E., Kinkendall, J.W., Burgess, M., 1987. Simultaneous determination of serum retinol and various carotenoids: their distribution in middle-aged men and women. J. Micronutr. Anal. 3, 27-45.

Storebakken, T., Choubert, G., 1991. Flesh pigmentation of rainbow trout fed astaxanthin or canthaxanthin at different feeding rates in freshwater and saltwater. Aquaculture 95, 289-295.

Storebakken, T., Foss, P., Schiedt, K., Austreng, E., Liaaen-Jensen, S., Manz, U., 1987. Carotenoids in diets for salmonids: IV. Pigmentation of Atlantic salmon with astaxanthin, astaxanthin dipalmitate and canthaxanthin. Aquaculture 65, 279-292.

Torrissen, O., 1985. Pigmentation of salmonids: factors affecting carotenoid deposition in rainbow trout (Salmo gairdneri). Aquaculture 46, 133-142.

Torrissen, O., 1986. Pigmentation of salmonids - a comparison of astaxanthin and canthaxanthin as pigments sources for rainbow trout. Aquaculture 79, 363-374.

Torrissen, O., Hardy, R., Shearer, K., Scott, T., Stone, F., 1990. Effects dietary canthaxanthin level and lipid level on apparent digestibility coefficients for canthaxanthin in rainbow trout (Oncorhynchus mykiss). Aquaculture 88, 381-386.

Weber, S., 1988. Determination of stabilised, added astaxanthin in fish feeds and premixes with HPLC. In: Keller, H.E. (Ed.), Analytical Methods for Vitamins and Carotenoids in Feeds. Roche Publication No. 2264, Basel, Switzerland, pp. 59-61.

Wornick, R.C., 1960. L'agglomération des aliments composés et ses effets sur les substances auxilliaires. Ind. Alim. Anim. 105, 31-48.

Yong, Y.Y.R., Lee, Y.K., 1991. A possible role of photoprotection for secondary carotenoids in the cytoplasm of the green alga Haematococcus lacustris (Chlorophyta). Phycologia 30, 257-261.

Zar, J.H., 1984. Biostatistical Analysis, 2nd edn. Prentice-Hall, Englewood Cliffs, NJ. 